Guidance for Processing

REDUCED OXYGEN PACKAGED (ROP)

OF RAW, FROZEN SEAFOOD

in Retail Operations 


\title{
Credits
}

The guidance for processing in retail operations has been prepared through support from the USDA Cooperative State Research, Education and Extension Service project no. 2001-11420 funded through the University of Florida in cooperation with Florida A\&M University and the Association of Food and Drug Officials (AFDO) during October 2001 through January 2004. Development of these respective guides was conducted by assigned voluntary Subcommittees combining academic, regulatory and industry expertise and a formal Steering Committee. The committee participants can be viewed in the Listing of Committee Members. The same information can be viewed at www.AFDO.org with additional visual aids and links to other website support and references. Design by Julissa Hernandez. Printed by IFAS Communication Services.

\section{Project Investigators}

Victor Garrido, University of Florida

Ray Mobley, Florida A\&M University

Steve Otwell, University of Florida

Keith Schneider, University of Florida

\section{Reduced Oxygen Packaging Subcommittee}

\author{
Shirley Bohm, MN Dept. Agric. \\ Steve Otwell * \\ Jeff Rhodehamel, Cryovac \\ Doug Saunders, VA Dept. Agric. \\ Jenny Scott, NFPA \\ Jon Woody, FDA \\ *Lead coordinator
}

\section{Project Steering Committee}

\author{
Jim Austin, AFDO \\ Shirley Bohm, FDA \\ Alfred Bugenhagen, NY Dept. Agric. \& Markets \\ Joe Corby, NY Dept. Agric. \& Markets \\ Carl Custer, USDA FSIS OPH B \\ Faye Felstein, FDA \\ Dan Sowards, TX Dept. of Health \\ Victor Garrido, University of Florida \\ Steven Grover, National Restaurant Assoc. \\ Janis McCabe, Publix Supermarkets, Inc. \\ Ray Mobley, Florida A\&M University
}

\author{
Steve Otwell, University of Florida \\ Paul Panico, $\mathrm{OH}$ Dept. of Agriculture \\ Gale Prince, The Kroger Co. \\ Fred Reimers, HEB Grocery Co. \\ Denise Rooney, AFDO \\ Doug Saunders, VA Dept. of Agriculture \\ Keith Schneider, University of Florida \\ Jenny Scott, Natl. Food Processors Assn. \\ Timothy Weigner, Food Marketing Institute \\ Gerald Wojtala, MI Dept. of Agriculture \\ Betsy Woodward, AFDO
}




\section{Background}

This guidance has been prepared in response to a notable increase in on-site retail processing (manufacturing) of foods traditionally processed in controlled plant environments. Such retail processing can involve, but is not limited to acidifying, smoking, drying, fermenting, curing, reduced oxygen packaging, and other operations that are traditionally done at a food manufacturing plant level. The key distinction for processing as related to this guidance is that the processing occurs on-site in the retail setting.

This guidance is intended for retailers and regulatory personnel to help understand the controls to implement in a retail operation in order to process and sell safe food products. It can be referenced in developing considerations for variances for any exception or special provision to state or local food safety or sanitary codes. It addresses those special variances required by the FDA Food Code which may require HACCP plans for those jurisdictions that have adopted those portions of the FDA Food Code. In addition, it also applies to regulatory oversight and/or approval for regulatory overlap that may occur between the states' processing requirements and the state or local retail food safety and sanitary codes. This guidance assumes retail compliance with applicable retail food codes, prerequisite standard sanitary operations procedures, and labeling requirements specified in 21 CFR 101. This guidance is not intended to replace or duplicate existing regulations, but it does offer a reference for more uniform practices.

\section{Disclaimer}

This guidance is not a binding set of requirements. The information provided in the guidance are recommendations based on current science, commercial experience and practical considerations as assembled by the assigned committees and reviewed by a variety of selected experts and the Project Steering Committee. Use of these recommendations would likely result in retail processing practices that are acceptable to the pertinent authorities for food safety. Retail compliance and enforcement will remain within the interpretations and decisions of the pertinent state and local regulatory authorities. 


\section{Product Description}

Product Description - This recommended guidance is for frozen seafood that is packaged in a manner that reduces the amount of oxygen in the package below the level normally found in air (anaerobic condition). This condition can alter the growth of spoilage bacteria that normally requires atmospheric oxygen levels (aerobic conditions) for growth. Reduced oxygen packaging (ROP) can include vacuum packaging, and modified or controlled atmospheric packaging (MAP or CAP). These packaging methods can provide the benefit of protecting the product during frozen storage while providing attractive, easy to handle packages with odor control, but in certain circumstances it can also present anaerobic conditions that are favorable for growth and toxin production by a potentially lethal pathogen, Clostridium botulinum.

Certain types of $C$. botulinum bacteria common to seafood, due to their freshwater and saltwater environments, can grow when products are exposed to temperatures above customary refrigeration. Previous studies have demonstrated that certain $C$. botulinum associated with seafood can grow at temperatures as low as $38^{\circ} \mathrm{F}$ $\left(3.3^{\circ} \mathrm{C}\right.$ ) and prolonged storage at $38^{\circ} \mathrm{F}$ (approx. $>25$ days) could result in dangerous, toxic conditions (1). Their growth and toxin production will increase as the exposure time and temperature increases. Due to the serious consequences with the $C$. botulinum toxins and the potential for pathogen growth while the seafood remains in anaerobic conditions, the use of ROP in retail processing of seafood is restricted to frozen seafood. Frozen storage prevents potential growth and toxin production by $C$. botulinum.

The most current version of the Food Code issued by the U.S. Public Health Service, FDA, recommends food establishments should not be allowed to package fish in ROP unless the fish is frozen before, during and after packaging (Food Code Section $3.502 .12-\mathrm{C}$ ). This recommendation is qualified to apply to all seafoods that are considered fresh, non-frozen or not previously processed to reduce the water activity (aw) or acidity $(\mathrm{pH})$ of the seafood such that it would prevent potential hazards due to $C$. botulinum. Note that regular, dedicated food processing operations with appropriate HACCP plans are allowed to use ROP with non-frozen seafood intended for retail distribution if their HACCP plans include at least two barriers to control the growth and toxin formation of $C$. botulinum (21 CFR Part 123; source http://www.access.gpo.gov/nara/cfr/waisidx_03/21cfr123_03.html).

1 Skinner, G.E. and J.W. Larkin. 1998. Conservative prediction of time to Clostridium botulinum toxin formation for use with time-temperature indicators to ensure the safety of food. J. Food Protection 61 (9) 1998: 1154 1160.

\section{Related terminology:}

Approved source - a source that has been determined to conform to principles, practices, and standards that protect public health.

Identifiable source - can include the name and address of the immediate supplier and the actual source or location of the supplies.

Hermetically sealed package - a package designed and intended to prevent entry of microorganisms (e.g., double seamed cans, glass jars with special lids, heat sealed plastic bags or containers).

Modified or controlled atmospheric packaging - the removal, replacement and/or continuous control of the atmosphere in a package with a mixture of gases that reduce the proportion of oxygen $(21 \%)$ normally present in air. Atmospheric changes can include various blends of carbon dioxide, nitrogen and other approved gases. In some cases, elevated oxygen would also be considered a modification that can retard growth of common spoilage bacteria. 
Potentially hazardous food - means a food that is natural or synthetic and that requires temperature control because it is in a form capable of supporting the rapid and progressive growth of infectious or toxigenic microorganisms or the growth and toxin production of Clostridium botulinum. Potentially hazardous food includes an animal food that is raw or heat-treated, shell eggs, or a food of plant origin that is heat-treated or consists of raw seed spouts, cut melons, and garlic-in-oil mixtures that are not modified in a way that results in mixtures that do not support growth as specified in this definition.

Reduced Oxygen Packaging (ROP) - packaging that reduces the normal amount or proportion of oxygen $(21 \%)$ found in air such that it creates anaerobic conditions that favor the growth of $C$. botulinum.

Vacuum Packaging - mechanical removal of air from packaging that prevents the transport of oxygen and sealing to prevent reentry of air. 
Flow Diagram of Operations
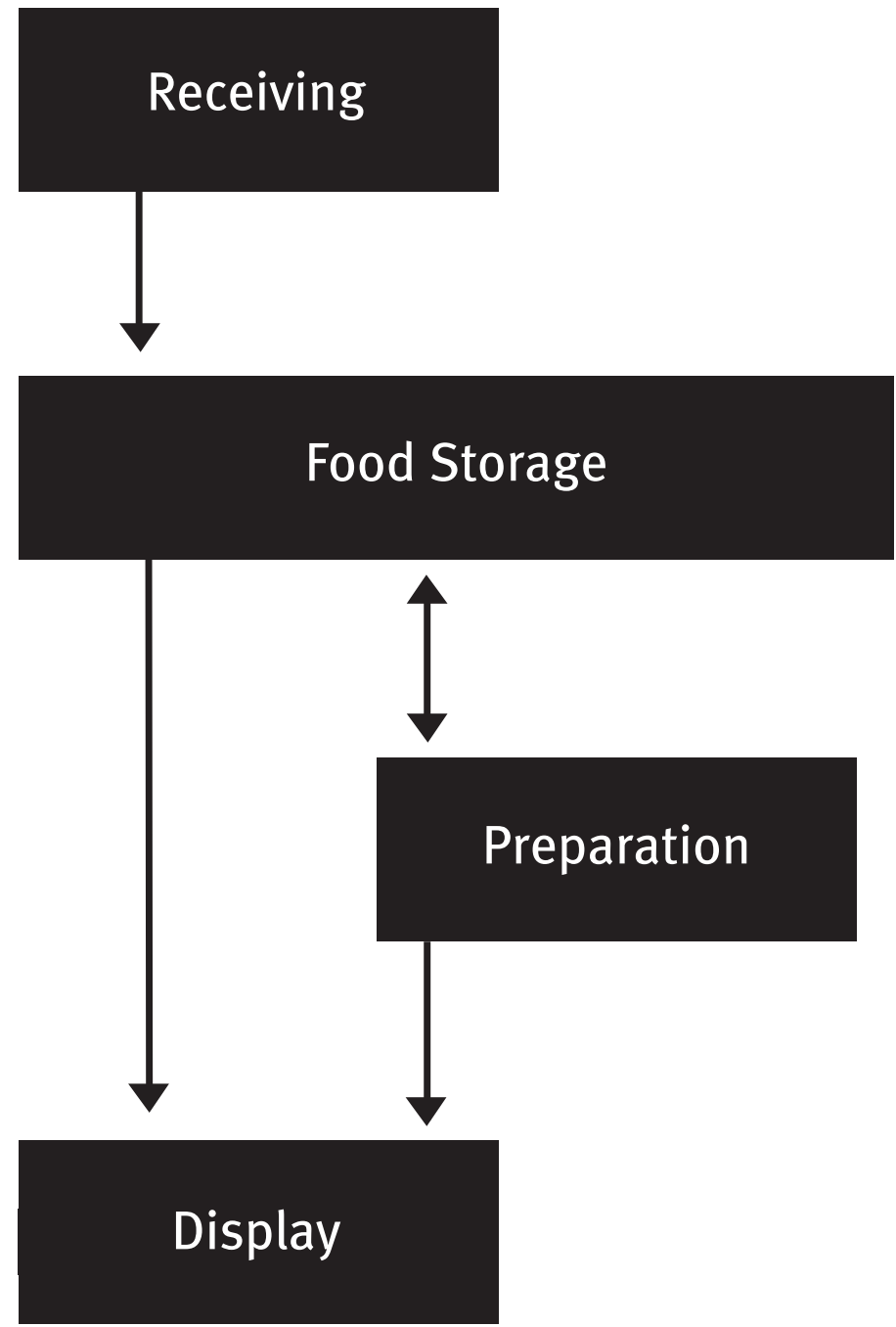


\section{Check List for Operations}

\section{Receiving}

All food is obtained from an identifiable, approved source. The source or supplier should be operating in accordance with applicable food safety requirements. Source identity can include the name and address of the immediate supplier that will be the first link to the actual source or location of the supplies. Identity of the supplier provides traceability of the food sources which can be important in food safety decisions. For seafood, this can include identity for approved harvest waters, prior handling conditions, and duration and methods of transport. No seafood from a recreational fisherman or other nonapproved sources is used in the sushi operations.

All seafood, including fish, shellfish, crustaceans, eggs (roe) and surimi comes from a source that operates under a HACCP plan. Evidence for such a source can include a letter from the supplier that indicates compliance with any pertinent HACCP requirements. In some instances, this HACCP information can be obtained upon request. The HACCP information and prior supplier agreements with the sushi operation should provide controls to prevent potential food safety hazards due to parasites in certain raw fish, elevated histamine levels in certain fish, and other seafood safety concerns (Appendix 1 - Food Safety Hazards).

It is recommended that all fish should be eviscerated and well cleaned prior to delivery to retail settings. Evisceration prior to retail handling will prevent cross-contamination of other foods and food contact surfaces. Fish viscera can contain high bacterial loads including $C$. botulinum. ROP should not be used for raw, fresh non-eviscerated seafood. If it is necessary to receive whole fish, they should be stored and eviscerated in an area and manner that would prevent cross-contamination of other food contact surfaces and foods.

All potentially hazardous foods are delivered at or below $4^{\circ}{ }^{\circ} \mathrm{F}\left(5^{\circ} \mathrm{C}\right)$ or solidly frozen. A calibrated thermometer is used to monitor the internal and/or surface temperature of the incoming foods before acceptance (Appendix 3 - Calibrations).

Retail establishment actively manages a program for routine inspection of incoming products for approved sources, product condition and temperature as necessary, integrity of packaging and proper label information, and documents product acceptance or rejection with dates, times and the person in decision, plus any necessary comments.

\section{Food Storage}

Food storage should be in appropriate temperature control units (freezers) capable of maintaining product temperatures at or below $0^{\circ} \mathrm{F}\left(-18^{\circ} \mathrm{C}\right)$. The foods may include raw ingredients or finished products which should be stored in separate units or segregated with adequate protection to prevent cross-contamination within the same unit. Refrigerated display counters are not considered storage units and should not be used to store raw ingredients or finished products prior to actual display.

The storage unit(s) are clean and orderly.

Products are contained and/or covered for protection.

Containers of seafood products or ingredients that are removed from the original (identified) packages are relabeled, marked for identification and dated.

Ready-to-eat items and items ready-for-display are segregated from products that require further handling or processing. 
Products are not stacked without adequate support and means to prevent any leakage between products.

Drippage is prevented into or on packaged products due to condensation, cooler pan leaks or other wet sources

Products are stored above the floor (approx. 6 inches) and away from walls and the ceiling. Storage includes containers, shelves, supports, pallets or other materials that do not absorb water and can be easily cleaned.

The schedule for product rotation should use a 'First-in First-out' rule (FIFO).

Refrigeration storage unit(s) are operating to assure the food can be maintained at or below $41^{\circ} \mathrm{F}\left(5^{\circ} \mathrm{C}\right)$.

Frozen storage unit(s) is operating to assure the frozen seafood are solidly frozen and maintained at or below $00 \mathrm{~F}\left(-18^{\circ} \mathrm{C}\right)$.

Display counters are not considered storage units and should not be used to store raw ingredients. Display counters for frozen ROP seafood must be maintained at or below $0^{\circ} \mathrm{F}\left(-18^{\circ} \mathrm{C}\right)$.

Routine monitoring for proper refrigerated storage unit temperatures involves use of a continuous timetemperature recording device or by periodic checks with a thermometer. All recorders and thermometers are calibrated periodically or as needed (Appendix 3 - Calibrations). When storage conditions above $41^{\circ} \mathrm{F}\left(5^{\circ} \mathrm{C}\right)$ are detected, an evaluation is conducted for all products stored in the unit. The evaluations will document considerations for the actual temperature of the products and duration of exposure. All suspect product is discarded.

\section{Preparation}

The work area, facilities and utensils should be designated or dedicated for the ROP operations. If it is necessary to share workspace and facilities, a schedule of operations, personnel traffic, product traffic and cleaning/sanitizing must be planned to prevent potential cross-contamination of other foods and food contact surfaces.

Standard Operating Procedures for basic sanitation and food safety are used and documented daily (Appendix 5 - Daily SOP Check List).

The preparation schedule should be arranged to prevent exposure of potentially hazardous foods for more than 4 hours outside of refrigeration.

\section{Preparation - ROP Frozen Seafood Products}

The potential for a seafood safety hazard with ROP seafood persists as long as the products remain in ROP or the original packaged condition. This period extends from the moment of packaging through retail display and consumer handling. For this reason, processing controls must be considered to account for the product safety until the package is opened or the product is exposed to atmospheric (aerobic) conditions.

All seafood should be frozen prior to ROP. The ROP frozen seafood should be maintained in a solidly frozen condition during distribution. The ROP packaging should be labeled to instruct consumers that the product should be held frozen and thawed under refrigeration immediately before use (e.g., "IMPORTANT - Keep frozen until used and thaw under refrigeration immediately before use"). 


\section{Display}

Display involves holding the finished ROP seafood products in temperature control units for a specified duration and condition for public sale.

The display should maintain frozen ROP seafood at or below $0^{\circ} \mathrm{F}\left(-18^{\circ} \mathrm{C}\right)$.

Product packaging is properly labeled and includes instructions for proper storage and thawing prior to use (Appendix 3 - Product Labels). 


\section{Appendices}

\section{Food Safety Hazards}

2. Calibrations

\section{Product Labels}

4. Daily SOP Check List 


\section{Appendix 1}

The following information and list of fish species with potential seafood safety hazards is based on FDA's "Fish \& Fisheries Products Hazards \& Controls Guidance" available in third edition (June 2001) from $<$ www.ifasbooks. ufl.edu> or by phone 800-226-1764 as publication no. SGR-121 (\$20) or it can be viewed at www.cfsan.fda.gov/ comm/haccp4.html. The retail processing of sushi must assure the use of proper controls to prevent, eliminate or reduce these potential hazards. The controls are often a shared responsibility between the supplier and retailer.

FISH:

The list of potential fish hazards includes live parasites, elevated histamine, and the natural toxin, ciguatera. The listing is by common names of certain related fish species. Retailers should consult the FDA Hazards Guide for the specific fish species in question. Species listed with concerns for live parasites would require freezing either by the supplier or retailer prior to serving a raw ready-to-eat food such as sushi.

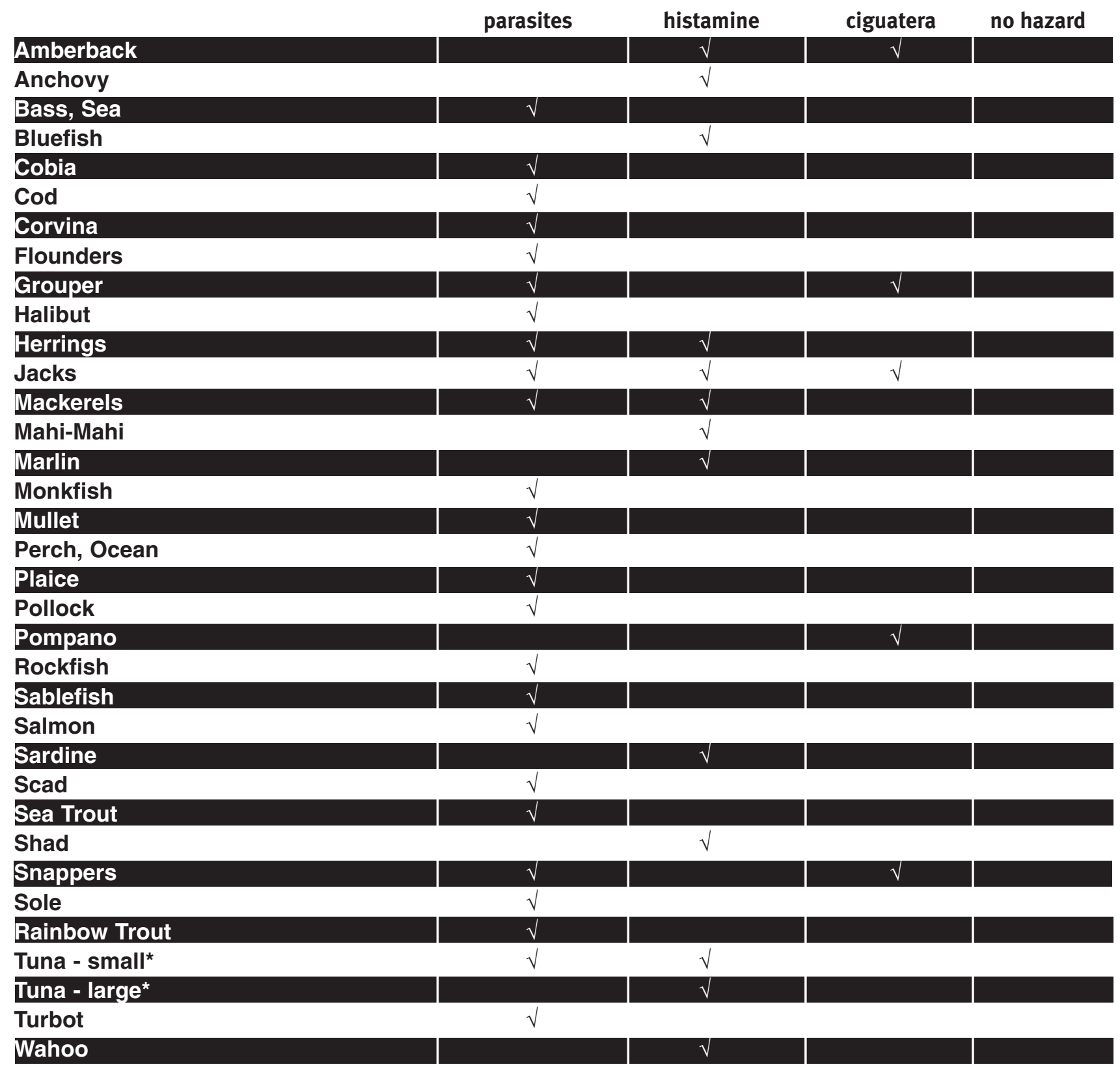

${ }^{*}$ For tuna, the concern for parasites is distinguished by species. The larger tuna (yellowfin, bluefin, blackfin, bigeye, and albacore) do not present a significant parasite problem that would require freezing prior to use in sushi. 
CRUSTACEANS (Shellfish):

Crab, Lobster and Shrimp - typically supplied as previously cooked items that are subject to bacterial crosscontamination after cooking. Retailers should question the processing procedures, and post-processing conditions and sanitation records prior to selecting a supplier.

\section{MOLLUSK (Shellfish):}

Clams, Oyster and Mussels - must be harvested from approved waters and handled by certified dealers that maintain harvest tags on shellstock or labels on the shucked products to identify the product harvest locations and dates. Retailers must check for the tags or label information on all deliveries of shellstock or shucked meats (meat removed from the shell). The shellstock tags must be stored in their retail establishment for 90 days.

Conch and Whelks - typically supplied as raw shucked meat (meat removed from the shell) that is subject to bacterial contamination during processing. Harvest tags are not required but suppliers should certify harvest from safe sites. Retailers should determine the processing conditions and sanitation records of suppliers as needed.

\section{Biological}

\section{Hazard: Parasites}

Problem: Consumption of certain raw seafood that may contain 'live' parasites that are naturally found in certain fish and could infect consumers.

Controls: Freezing or cooking of the fish or seafood product before consumption. According to FDA's Food Code, seafood is properly cooked when it reaches an internal temperature of $145^{\circ} \mathrm{F}\left(63^{\circ} \mathrm{C}\right)$ for 15 seconds. Freezing to kill potential parasites requires frozen storage at $-4^{\circ} \mathrm{F}\left(-20^{\circ} \mathrm{C}\right)$ or below for 7 days (total time), or freezing at $-31^{\circ} \mathrm{F}\left(-35^{\circ} \mathrm{C}\right)$ or below until solid and stored at $-31^{\circ} \mathrm{F}$ or below for 15 hours, or freezing at $-31^{\circ} \mathrm{F}$ or below until solid and stored at $-4^{\circ} \mathrm{F}$ or below for 24 hours.

\section{Hazards: Bacterial and Viral Pathogens}

Problem: Certain bacteria, i.e., Salmonella, Listeria and Vibrio spp. and certain viruses, i.e., Hepatitis A, noroviruses and others, can contaminate and, in the case of bacteria, grow on seafood.

Controls: Ensure that ingredients come from approved sources, monitor condition of incoming products, maintain and monitor proper temperatures and time in storage and preparation, practice proper hygiene, and monitor SOP's for sanitation.

\section{Hazard: Clostridium botulinum type $\mathrm{E}$}

Problem: Potential growth of the anaerobic bacteria and possible production of dangerous botulinum toxins in seafood packaged in ROP.

Controls: Frozen storage and ROP seafood product storage below $38^{\circ} \mathrm{F}\left(3.3^{\circ} \mathrm{C}\right)$ prevents growth of Clostridium botulinum. 


\section{Chemical}

\section{Hazard: Histamines}

Problem: Certain fish are prone to develop an elevated histamine content, the result of bacterial degradation of histidine, if they are thermally abused after harvest and during further handling. They can cause temporary illnesses in some people following consumption of the raw or cooked fish.

Controls: Ensure proper handling, time and temperatures that provide immediate and proper refrigeration or freezing of the fish as evident in a supplier's HACCP program, and continuing refrigeration or frozen storage until consumed. Retailers should examine each fish or fish portions carefully for signs of thermal abuse or initial decomposition. Questionable fish and fish with a temperature in excess of $410 \mathrm{o}$ should be rejected.

\section{Hazard: Ciguatera}

Problem: A natural toxin that can accumulate through the normal food chain of certain fish that can cause illness in some consumers when the fish is eaten raw or cooked.

Controls: Do not use certain fish species when harvested from known or designated areas that are problematic for ciguatera. The original producer or supplier's HACCP program should prevent the harvest and use of such fish. Potential problems can not be detected by sensory judgments of the raw or cooked fish. 


\section{Temperature Monitoring Devices - Thermometers}

Many types of thermometers and temperature recording devices are readily available for use in food handling operations. We recommend thermistors, thermocouples and infrared thermometers with either a digital or analog readout. All of these instruments are acceptable for use in the food processing operations as long as the operator understands how they are used and if they are calibrated for proper readings.

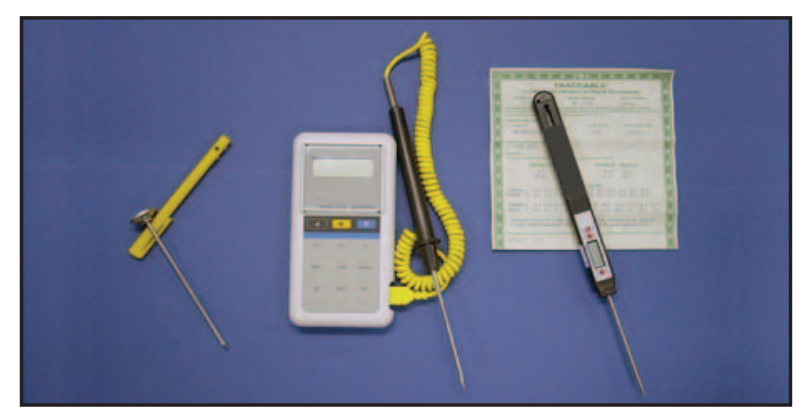

The method and frequency of calibration for thermometers will depend on the use and temperature range where the equipment is used. In the absence of manufacture's recommendations, thermometers should be calibrated at least once a month with more frequent calibrations when the instrument is physically abused or if the readings are questionable.

\section{Temperature Monitoring Devices (TMD) - Calibration Procedures (options):}

a. TMD's can be calibrated against a thermometer certified by the National Institute of Standards and Technology (NIST) by simply comparing both units at two preset temperatures (hot and cold).

b. TMD's can be calibrated using an ice-water slush. Insert the temperature probe into a mixture of ice and water slush and stir (2-3 $\mathrm{min})$ until the thermometer stabilizes. The probe should be at the center of the container. The thermometer should read $32 \pm 1^{\circ} \mathrm{F}\left(0 \pm 1^{\circ} \mathrm{C}\right)$. Adjust accordingly or discard and replace the faulty thermometer.

c. Hot point calibration is used when monitoring temperatures higher than room temperature (e.g., cooking temperatures). Heating blocks or boiling water can be used for this calibration. When using the boiling water procedure, the probe is placed inside a container with boiling water until the thermometer stabilizes (2-3 min). The probe should be at the center of the container. The thermometer should read $212 \pm 1^{\circ} \mathrm{F}\left(100 \pm 1^{\circ} \mathrm{C}\right)$ or appropriate temperature according to elevation (Table 1 - Altitude to Boiling Point of Pure Water Relationship). Adjust accordingly or discard and replace the faulty thermometer.

d. A combination of the procedures $b$ and $c$ is recommended for a more accurate calibration of thermometers used to monitor a wide range of temperatures.
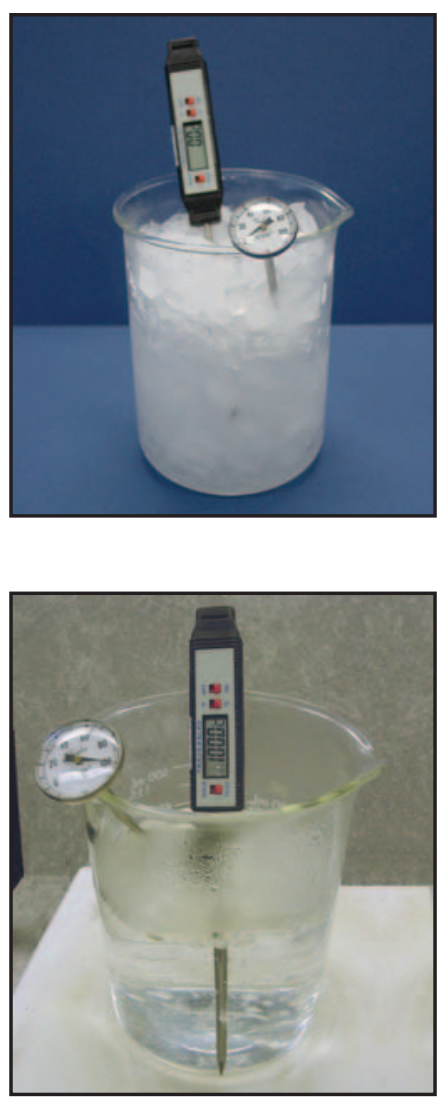


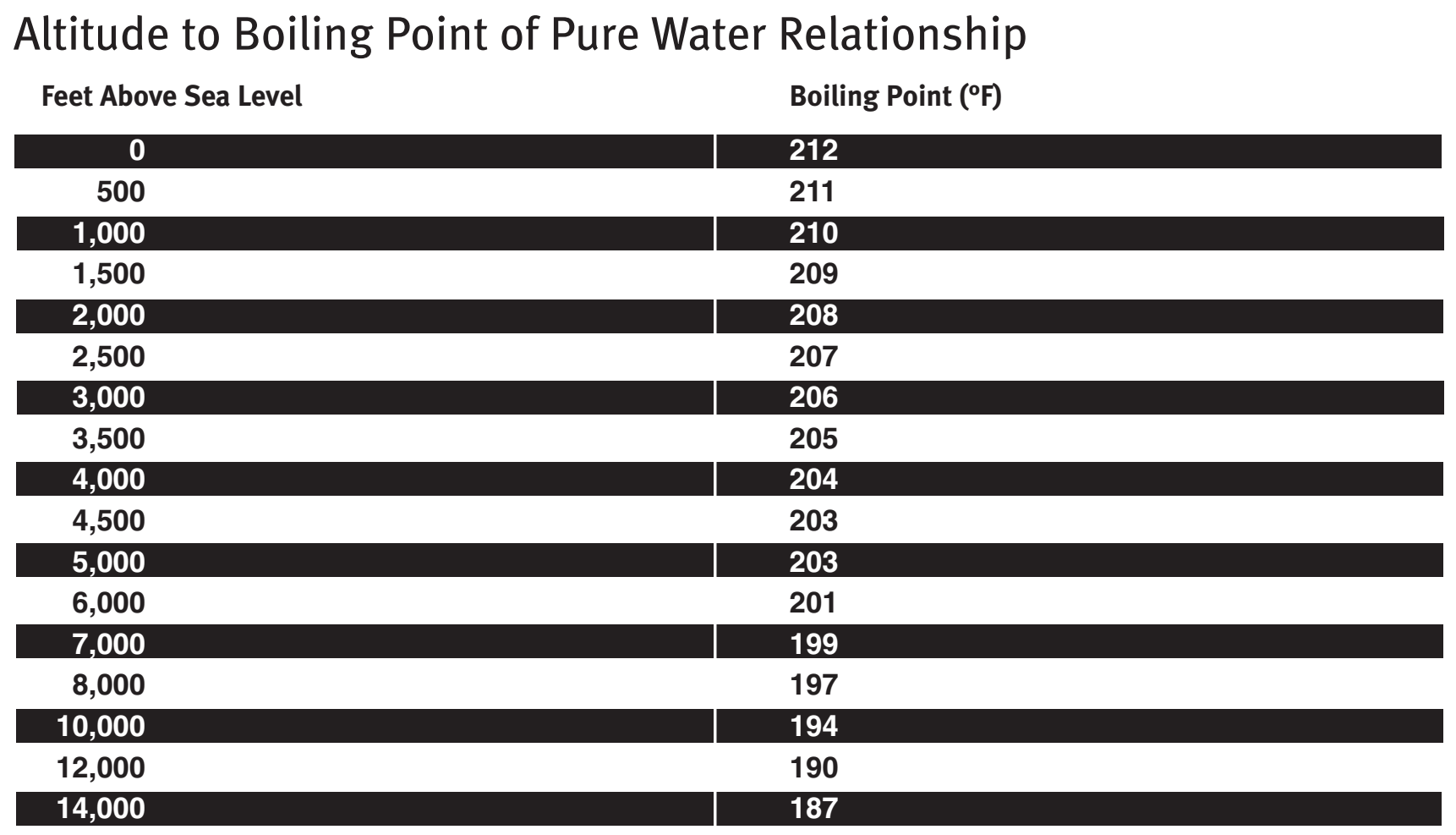

Source: Thermometer Calibration, food safety webpage, University of Nebraska Cooperative Extension (http://foodsafety.unl.edu/html/thermometer.html) 


\section{Appendix 3}

\section{Product Labels}

All specialty product sold through display in a retail setting must contain certain details on the product label that informs the consumer and could prevent potential food safety problems. The detail provided on this example includes both required and recommended information. The actual placement and size of the labeled information can vary. The example is enlarged for illustration.

\section{Label Information}

1. Identify specific seafood present. If made from two or more ingredients, list the ingredients in descending order by weight.

2. Include consumer instructions for handling frozen products (e.g., "IMPORTANT - Keep frozen until used, thaw under refrigeration immediately before use").

3. Lot and/or date coded.

4. Include the quantity of contents (weight) and the name and address of the food establishment.

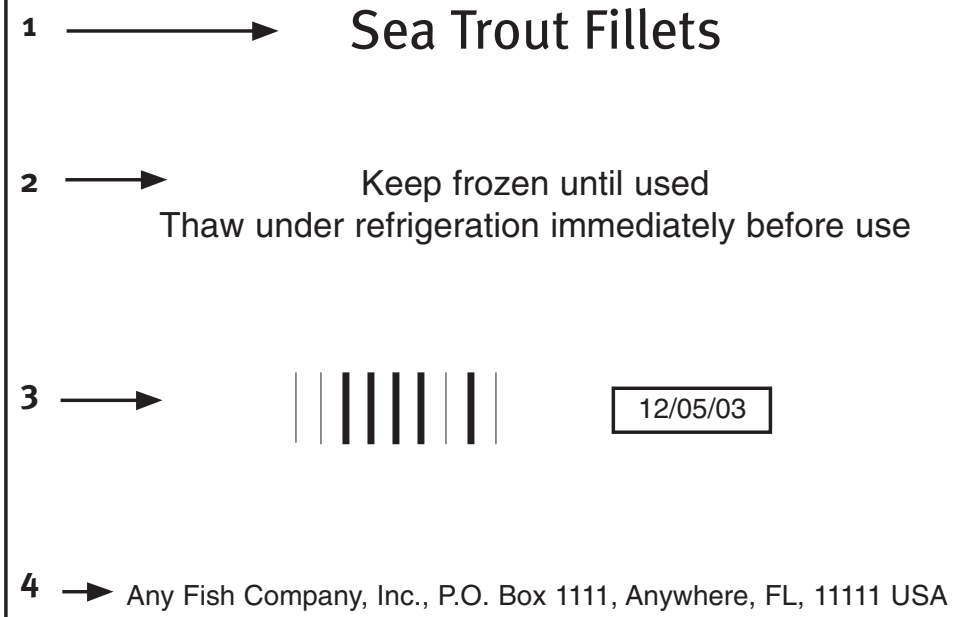

Note: This would not apply for bulk displayed items.

Disclaimer: This label is simply provided as a guide. Retailers should consult with their local authorities to assure compliance with more immediate requirements in their region 
Store Name/Number:

DATE:

\begin{tabular}{|c|c|c|c|c|}
\hline Storage & Time/Temp & Time/Temp & Time/Temp & Time/Temp \\
\hline Refrigerators ( $\left.{ }^{\circ} \mathrm{F} / \mathrm{Time}\right)$ & ${ }^{\circ} \mathrm{F}$ & ${ }^{\circ} \mathrm{F}$ & ${ }^{\circ} \mathrm{F}$ & ${ }^{\circ} \mathrm{F}$ \\
\hline Freezers ( $\left.{ }^{\circ} \mathrm{F} / \mathrm{Time}\right)$ & ${ }^{\circ} \mathrm{F}$ & ${ }^{\circ} \mathrm{F}$ & ${ }^{\circ} \mathrm{F}$ & ${ }^{\circ} \mathrm{F}$ \\
\hline Display & Time/Temp & Time/Temp & Time/Temp & Time/Temp \\
\hline Display temperature ( $\left.{ }^{\circ} \mathrm{F} / \mathrm{Time}\right)$ & ${ }^{\circ} \mathrm{F}$ & ${ }^{\circ} \mathrm{F}$ & ${ }^{\circ} \mathrm{F}$ & ${ }^{\circ} \mathrm{F}$ \\
\hline \multicolumn{5}{|c|}{$\begin{array}{l}\text { Clean and Orderly. Food in good condition } \\
\text { and properly labeled. }\end{array}$} \\
\hline \multirow[t]{3}{*}{ Sushi Rice Preparation } & & & & \\
\hline & & & & \\
\hline & & & & \\
\hline
\end{tabular}

Work Area

SOP CHECK LIST

Orderly; Clean and Sanitized tables, countertops and sinks. Orderly, all work surfaces cleared. Clean floor and drains

Proper storage and labeling of chemicals and cleaning items

Wet and dry trash separate and removed from work area.

All utensils, pots, pans, bowls, cutting boards, cooking or heating equipment properly cleaned and sanitized.

Thermometer and recorder available and calibrated

\section{Personnel}

Personnel Health, hand-washing practices, glove use, clean and well maintained outer garments, proper hair covering and no jewelry.

\section{Food Storage}

All food protected, dated and labeled properly

Refrigerators and freezers clean, orderly and operating correctly.

\begin{tabular}{l|l|l|l|l}
\hline \multicolumn{1}{c}{ Pre-Op Post-0p } & \multicolumn{1}{c}{ Time } \\
\hline Employee Initials & & & & \\
\hline Manager Review & & & & \\
\hline
\end{tabular}

This particular form is not mandated but it does indicate information that should be recorded to demonstrate an appropriate process for food safety. Different and additional forms can be used to record the same information. 


\section{Notes:}


1. This document is FSHN05-04, one of a series of the Food Science and Human Nutrition Department, Florida Cooperative Extension Service, IFAS, University of Florida, Gainesville, FL 32611. Published: February 2005. Please visit the EDIS Web site at http://edis.ifas.ufl.edu

2. Keith R. Schneider, PhD, assistant professor, University of Florida, Food Science and Human Nutrition Department, University of Florida, Gainesville, FL 32611; Victor Garrido, research coordinator and W. Steve Otwell, PhD, professor, Food Science and Human Nutrition Department, Aquatic Food Product Lab, University of Florida, Gainesville, FL 32611; and Ray Mobley, PhD, Florida A\&M University.

The Institute of Food and Agricultural Sciences is an equal opportunity/affirmative action employer authorized to provide research, educational information and other services only to individuals and institutions that function without regard to race, color, sex, age, handicap, or national origin. For information on obtaining other extension publications, contact your county Cooperative Extension Service office. Florida Cooperative Extension Service / Institute of Food and Agricultural Sciences / University of Florida / Larry R. Arrington, Dean 
